\title{
CURRENT INITIATIVES TO PROMOTE SOCIAL ENTREPRENEURSHIP IN BULGARIA
}

\author{
Venelin Terziev ${ }^{1}$ and Marin Georgiev ${ }^{2}$ \\ ${ }^{1}$ Academician of the Russian Academy of Natural History, Moscow, Russia, \\ Prof. D.Sc. (Ec.), D.Sc. (National Security), D.Sc. (Social Activities), Ph.D., National Military \\ University, Veliko Tarnovo, Bulgaria; University of Rousse, Rousse, Bulgaria, terziev@skmat.com \\ 2Ph.D., National Military University, Veliko Tarnovo, Bulgaria, clementon@abv.bg
}

\begin{abstract}
At present in the Bulgarian legislation there is no a legal act that gives the legal regulation of the activities of the social enterprise or social entrepreneurship. There is a fragmented legal regulation of individual sectors (social service providers, specialized enterprises for people with disabilities), where subjects engaged in activities are covered by social enterprises, but this approach is rather negative effect on the development of a coherent state policy to support the social economy and social enterprises, which ultimately reflects on their sustainability and efficiency. To clear structuring of the social economy sector in Bulgaria legislative changes should be undertaken and improvement of legislation to create preconditions for adequate legal and statistical recognition of the subjects of the social economy.
\end{abstract}

Keywords: social entrepreneurship, social enterprises, current initiatives, unemployed, employed.

\section{INTRODUCTION}

In 2011 the European Commission launched a targeted policy for the recognition of the role and support of the social economy titled "Social Business Initiative“ - creating a favorable climate for social enterprises, key stakeholders in the social economy and innovation (2011). Commission puts social economy and social innovation central to its agenda, both in terms of approximation of the levels of territorial development and in the search for innovative solutions to the problems facing society, especially in combating poverty and social exclusion. The European Commission social enterprise is a participant in the social economy whose main objective is rather the provision of beneficial social impact rather than generate profit for owners or partners. It operates in the market by supplying goods and services in an entrepreneurial and innovative way and uses a revised gain mainly for social purposes.

\section{MEASURES AND PROGRAMS TO PROMOTE EMPLOYMENT IN SOCIAL ENTERPRISES}

The policy on employment promotion is regulated by the Law on Employment Promotion (LEP) and its implementing Rules, which governs the different groups of programs and incentives for employers to create jobs, stimulate entrepreneurship, education and training for representatives of different target groups. The law does not contain provisions which directly regulate the promotion of social entrepreneurship, but in 
practice account target groups targeted by most of the measures, the latter are applicable to social enterprises.

According to EPA, several institutions are set out in the legal framework for conducting encouraging policy in the labor market.

Employment Agency is the executive body for the implementation of state policy in the field of employment, protection of the labor market, vocational information and counseling, training of unemployed and performing intermediary services. The National Council for Promotion of Employment, which created the Ministry of Labour and Social Policy, an advisory body in developing employment policies. By decision of the Board of meetings than regular members (they are defined by the Council of Ministers, representative organizations of employers and workers) may be present and representatives of other non-profit organizations. The district councils act Committees on Employment, which is created by the Regional Development Council, Council of Ministers and body for regional development of employment. In addition to these committees at regional level act Cooperation Council, which created the relevant divisions of the Employment Agency - labor offices and carry out direct supervision and control over the implementation of employment policy.

Tools to promote employment are creating programs and measures are developed and implemented in compliance with the requirements of the Law on Employment Promotion and regulations for its implementation. The financing of active policies to promote employment becomes annually by the State Budget Act. Every year it prepares a National Action Plan for Employment, taken by the Cabinet of the Minister of Labour and Social Policy. In the national plan shall specify the programs that will be implemented during the year, the target groups that will be targeted priority active employment policy during the planning year, and bet size of financial subsidies that will benefit employers involved in measures and programs employment promotion.

Financial incentives to promote employment

As intended the funds to be provided for the implementation of programs and measures for employment are shared among employers, unemployed and training organizations. Incentives and preferences for employers in several directions in order Task Force recruitment of young long-term unemployed, people with disabilities, war invalids, single parents and other vulnerable groups, education and vocational training for newly recruited people to develop entrepreneurship of unemployed persons. To participate in the programs and soft employment promotion, social enterprises must meet the following conditions:

- You need to employ persons targeted by the relevant divisions of the Employment Agency, to qualify for inclusion in the promotion measure;

- Shall request of vacancies and a written request to direct unemployed;

- To have a contract with the employment office;

- Provide Document average number of employees for the last six months in cases where it is required for use of preference;

- they should not have received state aid, regardless of the form and its source, totaling over $200000 \mathrm{lev}$ for the last three years;

- To submit a written declaration of lack of public obligations.

Each year National Action Plan for Employment determine the size of the funds allocated for implementation of programs and measures to promote employment. The modalities and criteria for the use of incentives to implement incentives are determined by the implementing regulation of the law. The law and regulations provide the general framework of the regime for the use of preferences. In the individual programs may provide for additional conditions and requirements for the candidates employers. The funds are provided based on the contract between the territorial division of the Employment Agency and employers, the contract must specify the type of program or measure to promote employment.

Provide funds for salaries and social security contributions or for contributions (and means of training measures including any). If the employer fails to fulfill its obligations and does not use the funds for their intended purpose, it due to their return together with statutory interest. Grants may be awarded until exhausted, as enshrined in the state budget for the calendar year.

Employers who terminate employment before the expiry of the promotion measure and the additional period equal to the period of subsidization and this is not related to failure to fulfill the work obligations and not spend the funds as intended, should repay them with a legitimate interest. There are exceptions to this: 
when the company closed in bankruptcy proceedings and others.

Programs to promote employment

According to the EPA Council of Ministers, Ministry of Labour and Social Policy, Employment Agency and other institutions and social partners develop and offer financing programs to increase employment, which are consistent with the priorities adopted the National Action Plan for Employment, National economic plan and the National plan for regional development.

National programs responsible institutions in developing and implementing their MLSP and Employment Agency. These programs are approved by the Minister of Labour and Social Policy in consultation with the social partners and the National Council for Promotion of Employment. The approved programs are offered for financing and inclusion in the National Action Plan for Employment and the Action Plan on Employment Agency. Branch programs comply with the relevant line ministries together with industry trade organizations, chambers of commerce, MLSP and Employment Agency.

For regional programs comply with the Employment Commissions with the District Councils.

Can be developed and employment programs, literacy, vocational training for disadvantaged groups, which under the Law on Employment Promotion are groups of unemployed people with low competitiveness on the labor market, which include unemployed youth ; unemployed youth with disabilities; unemployed youths from social institutions graduates; long-term unemployed; unemployed persons with disabilities; unemployed persons - single parents (adoptive parents) and / or mothers (adopters) with children up to age 3; unemployed persons who have served a term of imprisonment; unemployed women over the age of 50 and unemployed men over the age of 55; other groups of unemployed people.

Terms and conditions for use of preferences in employment programs and training are defined in the program and / or regulations and are approved by the Minister of Labour and Social Policy. Employers social enterprises if they meet the criteria set out in the specific program can apply on it. Information on current programs and intermediary services targeting of unemployed persons can be obtained from territorial divisions of the Employment Agency nationwide.

Measures to promote employment

Measures to promote employment are enshrined in law and defined target group - the addressee of the measure. There is no obstacle for social enterprise employer to use preference simultaneously measure prescribed by law and employment program as long as they perform their duties and to meet the conditions and requirements of the program, respectively measure.

There are financial subsidies for social enterprises employers who create jobs for:

- Unemployed people under 29 years of age;

- War invalids;

- Youth (under 29) with disabilities and persons with disabilities;

- Youths from social institutions graduates;

- Long-term unemployed - continuous registration in the labor office more than 12 months;

- Single parents or adoptive parents and / or mothers or adoptive mothers with children up to age 3;

- Persons who have served a sentence of imprisonment;

- Unemployed, employed part-time;

- Unemployed people with disabilities employed on a seasonal, temporary or part-time work;

- Unemployed women over the age of 50 and men over the age of 55. Employers - social enterprises may participate in measures relating to training and further training of newly hired unemployed or already employed, as well as active measures to protect and preserve the Employment Promotion Act.

An interesting hypothesis is the possibility of social enterprises employers the status of micro-enterprises under the Law for SMEs to get financial aid for the first five jobs created, which hired unemployed targeted by labor offices.

In a special section of the law provides for measures to stimulate entrepreneurship. The law allows unemployed persons entitled to compensation wishing to independently start a business, submit a business project that, if approved, individuals are provided a lump sum at the expense of fund "Unemployment" (the 
person must declare that It agrees to receive this lump sum instead of cash benefits or unemployment benefits). If business project employs another unemployed family member, and provide additional funds. Persons whose business projects were approved, perform and record his business under current legislation.

Recent amendments to the EPA predicted that unemployed persons registered micro Act for small and medium-sized enterprises can use funds to start their own business by approved by the territorial division of the Employment Agency business project, if not already exercised its rights under law, i. e. have not received funding approved another project or business plan for agricultural activity.

Besides the financing of business projects of individuals recover costs for external consulting services and provide means for acquiring professional qualification in the subject of business and / or management of the project approved (Terziyev, 2019; Terziev, Bencheva, 2019a; Bencheva, Stoeva, Todorova, 2018; Bencheva, Tepavicharova, 2016; Tepavicharova, Bencheva, 2016a; Bogdanova, 2018a; Terziev, 2019b-c; Terziev, Bekiarova, Georgiev, 2019d; Bencheva, Stoeva, 2019e).

\section{FUNDING OPPORTUNITIES FOR EUROPEAN AND OTHER FUNDS AND PROGRAMS}

In the current programming period 2014-2020 social entrepreneurship in Bulgaria will be financed under the Operational Programme "Development of Human Resources“ priority 2 "Reducing poverty and promoting social inclusion," particularly in the procedure "Development of social entrepreneurship." The aim of the procedure is to facilitate access to employment and to provide support for social inclusion of vulnerable groups by creating appropriate conditions for their professional integration. The activities should be aimed at supporting the creation of new business and expansion of existing social enterprises specialized enterprises and cooperatives of people with disabilities in relation to employment. It is expected to be opened this year and has a budget of 15 million Lev (Petkova, 2008, Petkova, 2009; Petkova - Georgieva, Yanakieva, 2012; Petkova, Strateva, 2012a; Petkova, Tasheva, Petkov, 2018b-c).

Territorial cooperation programs (PTSD) also offer many opportunities for financing social entrepreneurship. In PTSD Greece-Bulgaria 2014 - 2020 one of the thematic objectives and investment priorities is "Increasing the capacity of social enterprises in the border region." The activities for which beneficiaries can apply are:

- Support the creation and operation of social enterprises that provide innovative solutions and promote labor market and social services among the population of the border region

- Supporting social "franchise", including exchange of business models between cross-border social enterprises

- Support the development and implementation of methodologies for monitoring and evaluation of social, economic and environmental impacts on the development of the border region.

In Balkans-Mediterranean 2014 - 2020 will be assisted networking for collaboration between social entrepreneurs from the region in order to promote this economic sector and to create sustainable jobs in border regions.

In other regional programs, social entrepreneurship is not exported as a separate priority, but at the expense of inclusion of different social target groups will be prioritized in the evaluation of projects. Such is the case for example with cross-border program with Serbia, which will finance projects to support youth entrepreneurship. The Strategy for the Danube Region in Bulgaria for the new programming period one of the main priorities is the integration of disadvantaged people. Social entrepreneurship is affected in EU framework programs - the program for research and innovation "Horizon 2020" and the education program "Erasmus +" where are prioritized two main aspects of social entrepreneurship - youth employment and lifelong learning. Eligible activities are analysis and development of strategies to deal with the social problem and improve the training of young people and other age groups or those with disabilities.

Recommendations to improve the legal and institutional environment for the development of social enterprises.

Social entrepreneurship is a well known concept in most European countries. Social enterprises in these countries carry significant share of activities in the social sphere, combining the generation of income from doing business and achieving certain social effect. Social entrepreneurship is unique in that it allows the integration of economic and social objectives into one, which allows for effective social policy and provides efficient support to socially vulnerable groups of society in the broadest sense.

The Bulgarian legislation lacks legal definition of social enterprise, and rules governing the status and form of the activities of the social enterprise. 
Despite the lack of legal framework, the practice in Bulgaria shows that there are organizations that promote social entrepreneurship and identify themselves as social enterprises. However, to make this a sustainable policy that has real results for people is necessary not only piloting different models, but better institutionalize the legal framework that will stabilize each intervention and will provide long term investment. To this must be added the appropriate stimulating fiscal policy to ensure through positive discrimination that "equal chance" with ordinary business will be provided (Stoeva, 2016b-c; Arabska, 2016d; Ovcharova, 2017-a).

- According to the current Bulgarian legislation there is no explicit legal regulation of social enterprises, but that does not mean that such forms are not found in practice.

- The existing social enterprises have different legal forms of legal entities of current legislation (NGOs, trade associations, cooperatives), it is important to be applied the criterion of real social impact.

- In some cases, provided additional registrations, but this is according to the sectoral focus of specific activities.

- The fragmented legislation (according to sectors - social service providers, specialized enterprises, etc.) Affects the development of a coherent government policy to support the social economy and social enterprises, which ultimately reflects on their sustainability and efficiency.

\section{SUGGESTIONS}

1. To regulate the level of law the main characteristics to identify social enterprises with a view to their more favorable tax treatment. It is not necessary the formation of a separate legal form of social enterprise since currently Bulgarian legislation through the Trade law and the legal non-profit provides ample opportunities for association of persons and achieve set them socially significant goals. More important here is to create conditions for development of their activities to achieve added value towards social inclusion of various vulnerable groups.

2. To regulate various tax breaks when operating as a social enterprise or implementation of the services / goods produced within this activity.

3. To create an active electronic register of social enterprises in the Republic of Bulgaria. The register should integrate and current register of commercial companies and cooperatives of people with disabilities, led by the Agency for Persons with Disabilities. Its main objective should be to identify best practices and replicable models, to develop together with the parties concerned full map of social enterprises in Bulgaria by determining their characteristics, their economic models, economic weight, their potential for cross-border growth content and criteria of legal statutes and tax regimes, and existing mechanisms.

4. To create easier access and procedures for the participation of social enterprises as contractors of public works - widening the circle of persons acting art. In 16 of the Public Procurement Act /PPA/, as well as mechanisms to ensure the implementation of the regulations.

5. To draw awareness simplified procedures for employers' social enterprises - what documents should prepare by hiring disabled / disadvantaged people / in order to avoid the administrative burden on employers, and subsequent sanctions by EA "Labour Inspectorate".

6. To develop more measures aimed at promoting and supporting the activities of social enterprises in order to build capacity and competitiveness and development of innovation; programs may be funded under operational programs.

7. To facilitate access to finance for social enterprises at the start of their activities, their development and expansion by investing in social investment funds that provide equity instruments and debt financing.

8. Search for opportunities to use the programming period 2014-2020 for planning and funding for the implementation of national and local policies to promote social entrepreneurship.

\section{CONCLUSION}

Provided at the time tax concessions are insufficient to stimulate real development of social entrepreneurship in Bulgaria - primarily exist incentives to donors - corporate and to a lesser extent to donors - physical persons which measure is more encouraging corporate social responsibility; There are no significant tax incentives for operating as a social enterprise; What exists a policy of financial incentives is largely directed only towards entrepreneurship as one of the vulnerable groups - people with disabilities; Surely part of a good legal framework, securing a supportive environment for the development of social enterprises is explicit regulation of specific tax relief to all who meet the definition and the result of social enterprise, and that in view of the work done(Terziev, Nichev, Georgiev, 2019f-g). 
This report provides an analysis of the development of social entrepreneurship in Bulgaria according to: International project Social enterprise skills for business advisors - SESBA of the European program for education, training, youth and sport "Erasmus +", Grant Agreement №2015-1-EL01-KA202-014097 (20152018).

\section{REFERENCE LIST}

Social Business Initiative - Creating a favourable climate for social enterprises, key stakeholders in the social economy and innovation, (2011). COM(2011) 682 final, 2012/C 229/08.

Terziyev, Venelin. (2019). Sotsial'naya ekonomika i sotsial'noye predprinimatel'stvo. // Sovremennyy menedzhment: problemy i perspektivy: sbornik statey po itogam XIV mezhdunarodnoy nauchnoprakticheskoy konferentsii «Sovremennyy menedzhment: problemy i perspektivy» 25-26 aprelya 2019 goda, Ministerstvo nauki i vysshego obrazovaniya Rossiyskoy federatsii, Izdatel'stvo SanktPeterburgskogo gosudarstvennogo ekonomicheskogo universiteta, Sankt-Peterburg, Rossiya, 2019, s. 412-435, ISBN 978-5-7310-4567-4 (Терзиев, Венелин. Социальная экономика и социальное предпринимательство. // Современный менеджмент: проблемы и перспективы: сборник статей по итогам XIV международной научно-практической конференции «Современный менеджмент: проблемы и перспективы» 25-26 апреля 2019 года, Министерство науки и высшего образования Российской федерации, Издательство Санкт-Петербургского государственного экономического университета, Санкт-Петербург, Россия, 2019, с. 412-435, ISBN 978-5-73104567-4).

Terziev, V, Bencheva, N. (2019a). Current status of social entrepreneurship in Bulgaria. // Advances in Bulgarian science'2018, National centre for information and documentation (NACID), Sofia, 2019, pp.5-18, ISSN 1314-3565.

Bencheva, N., Stoeva, T., Todorova, S. (2018). Key Skills and Competences for Social Business Advisors: Views from Experts, International Journal of Organizational Leadership, 7(2018), pp.413-425; ISSN 2383-1103 (Print); ISSN 2345-6744 (Online).

Bencheva, N., Tepavicharova, M. (2016). Support structures for social entrepreneurship in Bulgaria, The first scientific conference on social entrepreneurship on "Tips, skills and tools for consulting social entrepreneurs", pp.29-35, ISBN 978-954-517-249-6 ISBN 978-954-517-250-2.

Tepavicharova, M., Bencheva, N. (2016a), Factors for development of the educational and professional qualitication profile of the managers from the services sector in Bulgaria, Scientific journal «Economics and Finance», Science and Practice, Conference proceedings, Citation Index - Social Sciences \& Humanities (CPCI-SSH), Thorpe-Bowker, Melbourne, Australia, pp.42-47, ISBN 978-0-9942661-3-2.

Bogdanova, Margarita. (2018a). Policies and Instruments for Social Development. Journal of Innovations and Sustainability, Plovdiv, Bulgaria, 4, 2018, 1, pp. 59-63, ISSN 2367-8127 (CD-ROM), ISSN 23678151 (ON-LINE).

Petkova, St., (2008). Balanced scorecard as instrument of strategic controlling, Forum Gesundheit und Soziales, Beitrage aus Lehre, Forschung und Praxis der Studiengange der Evangelischen Fachhochschule Berlin, Heft 6, p.60-68, ISSN 1863-1851, Berlin, 2008.

Petkova, St. (2009). Tendentsii za upravlyavane na strategicheskiya risk s pomoshtta na balansirani sistemi ot pokazateli, Godishnik na MGU „Sveti Ivan Rilski”, tom 52, str.87-91, ISSN 1312-1820, Sofiya, 2009 (Петкова, Ст., Тенденции за управляване на стратегическия риск с помощта на балансирани системи от показатели, Годишник на МГУ „Свети Иван Рилски”, том 52, стр.87-91, ISSN 13121820, София, 2009).

Petkova - Georgieva, St., A., Yanakieva, (2012). Balansiranata sistema ot pokazateli kato savremenen metod na upravlenie $v$ turisticheskoto predpriyatie, akademichno spisanie "Upravlenie i obrazovanie", tom VIII, kn. 1, str.140-144, ISSN 13126121, Burgas, 2012. (Петкова - Георгиева, Ст., А., Янакиева, Балансираната система от показатели като съвременен метод на управление в туристическото предприятие, академично списание “Управление и образование”, том VIII, кH. 1, стр.140-144, ISSN 13126121, Бургас, 2012). 
Petkova, St., Iv. Strateva, (2012a). Opredelyaneto na strategicheskite vrazki po deynosti kato klyuchov podhod v kontrolinga, godishnik na Universitet "Prof. d-r Asen Zlatarov", Br. XLI, kn. 2, str.106-112, ISSN 1312-1359, Burgas, 2012 (Петкова, Ст., Ив. Стратева, Определянето на стратегическите връзки по дейности като ключов подход в контролинга, годишник на Университет “Проф. д-р Асен Златаров", Бр. XLI, кH. 2, стр.106-112, ISSN 1312-1359, Бургас, 2012).

Petkova, S., Tasheva, Y., P. Petkov, (2018b). Assessment of the Pyrolytic Fractions from Refused - Derived Fuel, Oxidation Communications, p. 462 - 467, book 41, vol. 3, ISSN 0209-4541, 2018.

Petkova, S., Tasheva, Y., P. Petkov, (2018c). Evaluation of Possibility to Use Liquid Pyrolysis Fractions as Fuel, Oxidation Communications, p. 468 - 474, book 41, vol. 3, ISSN 0209-4541, 2018.

Terziev, Venelin. (2019b). Social policy and labor market development in Bulgarian transition period. INTCESS 2019- 6th International Conference on Education and Social Sciences, 4-6 February, 2019, Dubai, International Organization Center of Academic Research, 2019, pp. 703-714, ISBN: 978-60582433-5-4.

Terziev, Venelin. (2019c). Theoretical basis of development of labor market and social policy in the republic of Bulgaria. INTCESS 2019- 6th International Conference on Education and Social Sciences, 4-6 February, 2019, Dubai, International Organization Center of Academic Research, 2019, pp. 715-726, ISBN: 978-605-82433-5-4.

Terziev, V., Bekiarova, N., Georgiev, M. (2019d). Support structures for the development of social entrepreneurship. // KNOWLEDGE - Capital of the future, International Journal Scientific Papers Vol. 29.1, February, 2019, Institute of knowledge management - Skopje, Macedonia, 29, 2019, N 1, pp. 21-25, ISSN 1857-923X (for e-version), ISSN 2545 - 4439 (for printed version).

Bencheva, N., Stoeva, T. (2019e). The role of management skills in social entrepreneurship: expert assessment. // 20th International conference - Knowledge without borders, Vrnjacka Banja, Serbia (29-31.03.2019), Institute of knowledge management - Skopje, Macedonia, 30, 2019, N 6, pp. 15931597, ISSN 1857-923X (for e-version), ISSN 2545 - 4439 (for printed version).

Stoeva, Teodora. (2016b). Predizvikatelstva i potrebnosti ot obucheniya na sotsialnite biznes konsultanti. // Parva nauchna konferentsiya po sotsialno predpriemachestvo. Saveti, umeniya i instrumenti za konsultirane na sotsialnite predpriemachi. Agraren Universitet Plovdiv, 2016, str. 71-74 (Стоева, Теодора. Предизвикателства и потребности от обучения на социалните бизнес консултанти. // Първа научна конференция по социално предприемачество. Съвети, умения и инструменти за консултиране на социалните предприемачи. Аграрен Университет Пловдив, 2016, стр. 71-74).

Stoeva, Teodora. (2016c). Sotsialni deynosti v obshtina Plovdiv. // Parva nauchna konferentsiya po sotsialno predpriemachestvo. Saveti, umeniya i instrumenti za konsultirane na sotsialnite predpriemachi. Agraren Universitet Plovdiv, 2016, str. 111-117 (Стоева, Теодора. Социални дейности в община Пловдив. // Първа научна конференция по социално предприемачество. Съвети, умения и инструменти за консултиране на социалните предприемачи. Аграрен Университет Пловдив, 2016, стр. 111-117).

Arabska, Ekaterina.(2016d). Iziskvaniya za umeniya ot konsultantite za osiguryavane na efektivna podkrepa na sotsialnite predpriyatiya. // Parva nauchna konferentsiya po sotsialno predpriemachestvo. Saveti, umeniya i instrumenti za konsultirane na sotsialnite predpriemachi. Agraren Universitet Plovdiv, 2016, str. 75-81 (Арабска, Екатерина. Изисквания за умения от консултантите за осигуряване на ефрективна подкрепа на социалните предприятия. // Първа научна конференция по социално предприемачество. Съвети, умения и инструменти за консултиране на социалните предприемачи. Аграрен Университет Пловдив, 2016, стр. 75-81).

Ovcharova, S. (2017). Motivation in knowledge economy. // 6th International congress Knowledge Economy \& Management, 26-28.12.2007, Istanbul, Turkey, 2017, pp.1643-1651. ISSN: 1308-3937.

Ovcharova, S. (2017a). Knowledge management in some Bulgarian organizations. // 6th International congress Knowledge Economy \& Management, 26-28. 12.2007, Istanbul, Turkey, 2017, pp.19081915. ISSN 1308-3937.

Terziev, V., Nichev, N., Georgiev, M. (2019f). Current status of social entrepreneurship: social enterprises and state. // 20th International conference - Knowledge without borders, Vrnjacka Banja, Serbia (2931.03.2019), Institute of knowledge management - Skopje, Macedonia, 30, 2019, N 6, pp. 1587-1591, ISSN 1857-923X (for e-version), ISSN 2545 - 4439 (for printed version). 
Terziev, V., Nichev, N., Georgiev, M. (2019g). Social enterprises and their impact in Bulgaria. // 20th International conference - Knowledge without borders, Vrnjacka Banja, Serbia (29-31.03.2019), Institute of knowledge management - Skopje, Macedonia, 30, 2019, N 6, pp. 1645-1649, ISSN 1857923X (for e-version), ISSN 2545 - 4439 (for printed version). 